\section{Species persistence: a re-look at the freshwater fish fauna of Chennai, India}

\section{J.D. Marcus Knight ${ }^{1}$ \& K. Rema Devi $^{2}$}

${ }^{1}$ Flat 'L', Sri Balaji Apartments, $7^{\text {th }}$ Main Road, Dhandeeswaram, Velachery, Chennai, Tamil Nadu 600042, India

${ }^{2}$ Zoological Survey of India, Southern Regional Centre,

100 Santhome High Road, Chennai, Tamil Nadu 600028, India

Email: ${ }^{1}$ jdmarcusknight@yahoo.co.in, ${ }^{2}$ remadevi_zsi@yahoo.com

Chennai is amongst the few Indian cities that has had a long history of biodiversity studies. The erstwhile Madras that has since expanded considerably into today's Chennai has extensive and diverse aquatic habitats that amongst others attracted the attention of ichthyologists for at least 100 years. Two perennial rivers - Adyar and Cooum, numerous reservoirs that provide water for irrigation and drinking, seasonal tanks and extensive flood plains (example Pallikaranai Marsh), canals, channels, rice fields and open wells are typically freshwater habitats that add to the heterogeneity of the otherwise maritime landscape.

One of the earliest and most comprehensive of fish studies that considered a wide range of Chennai's aquatic habitats is that of Raj (1916). Raj's study carried out around 1910 is in fact the bench mark of the series of fish surveys that spanned the 100 years dealt with in this paper.

Raj (1916) recorded a total of 57 species of which 44 species may be treated as primary freshwater fishes (Menon 1999). He mainly surveyed the Adyar and Cooum rivers and sporadically the drinking water

Date of publication (online): 26 November 2010

Date of publication (print): 26 November 2010

ISSN 0974-7907 (online) | 0974-7893 (print)

Editor: R.J.R. Daniels

Manuscript details:

Ms \# 02519

Received 22 July 2010

Finally accepted 05 October 2010

Citation: Knight, J.D.M. \& K.R. Devi (2010). Species persistence: a relook at the freshwater fish fauna of Chennai, India. Journal of Threatened Taxa 2(12): 1334-1337.

Copyright: () J.D. Marcus Knight \& K. Rema Devi 2010. Creative Commons Attribution 3.0 Unported License. JoTT allows unrestricted use of this article in any medium for non-profit purposes, reproduction and distribution by providing adequate credit to the authors and the source of publication.

Acknowledgements: We thank Mr. Venkat, Dolphin Aquarium, and Mr. G. Das, Care Earth, Chennai, for their help in conducting the surveys.

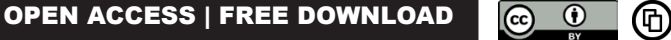

reservoirs of Sembarambakkam (Chembarampakkam) and Red Hills. Subsequent surveys of fish carried out by other authors focused mainly on the Adyar and Cooum rivers (Panikker \& Aiyar 1937; Ganapati 1964; Evangeline 1967; Mary Bai 1993) with a few surveying the Chembarampakkam Lake (Raghunathan 1978; Daniels \& Rajagopal 2004). The few other available publications are based on studies around Chennai and its environs (Devi et al. 1999) with a couple focusing on specific habitats (Raghunathan et al. 2005; Raghunathan et al. 2008).

The present study focused mainly on the freshwater habitats around Chennai such as the Rettai Eri (near Red Hills), Madipakkam Lake, wetlands of Velacherry, Kovillampakkam Lake, Adyar River and the Chembarampakkam Lake. Dipnet, dragnet and castnet were used for the surveys and in deep waters where these methods could not be used, fishermen's gill nets were regularly monitored.

A dip net of $45 \times 30 \mathrm{~cm}$ with mesh size less than $1 \mathrm{~mm}$, a cast net of radius $480 \mathrm{~cm}$ with mesh size $10 \mathrm{~mm}$ and a dragnet of dimensions $210 \times 120 \mathrm{~cm}$ with mesh size less than $1 \mathrm{~mm}$ were used, apart from regularly monitoring fishermen's catches. Fishermen used four types of gill nets approximately $400 \times 2 \mathrm{~m}$ each with different mesh sizes viz $25 \mathrm{~mm}, 40 \mathrm{~mm}, 55 \mathrm{~mm}$ and $100 \mathrm{~mm}$. The species collected were identified using the available literature on freshwater fishes (Talwar \& Jhingran 1991; Jayaram 1999).

The identity of a few primary freshwater fish which were recorded in the previous surveys conducted over the past hundred years by various authors (Raj 1916; Panikker \& Aiyar 1937; Ganapati 1964; Evangeline 1967; Raghunathan 1978; Bai 1993; Devi et al. 1999; Daniels \& Rajagopal 2004; Raghunathan et al. 2005; Raghunathan et al. 2008) have since undergone nomenclatural changes/ revisions and the present paper is based on the current identity and geographical distribution of the species.

Aplocheilus blockii is restricted to the west coast and very similar to $A$. parvus a species which is quite common in the Coromandel Coast (Menon 1999). Therefore in this paper the species present in Chennai and its environs is confirmed to be $A$. parvus which is frequently confused with A. blockii (Jayaram 1999) and a few authors even consider them as synonyms (Talwar \& Jhingran 1991).

The next species under question recorded in four surveys (Raghunathan 1978; Bai 1993; Devi et al. 1999; Raghunathan et al. 2008) is Colisa fasciata. This species is known to be a northern Indian species. C. Ialia a very similar species is known from Chennai from the 1960s (Daniels \& Rajagopal 2004) but did not feature in any of those surveys. Even though $C$. lalia was common for the past 50 years it was first officially reported only in 2004 (Daniels \& Rajagopal 2004) and subsequently in 2005 
(Raghunathan et al. 2005). As both the species are very similar with reddish cross bands on the body it is likely that they have been confused. Therefore it is presumed that the record of $C$. fasciata is indeed $C$. lalia which is very common even today in Chennai and its environs.

Earlier taxonomic revisions have replaced $O$. melastigma which is the next species in question with Oryzias dancena and O. carnaticus (Daniels 2002; Parenti 2008). Oryzias $s p$. reported in the other surveys is being treated as $O$. dancena as the male specimens collected during the present study had filamentous extensions of the anal fin (Daniels 2002) and smaller adult size (Parenti 2008).

Puntius mahecola recorded by Raj (1916) is actually $P$. filamentosus. The two have frequently been confused and occasionally treated as synonyms (Menon 1999). $P$. mahecola is now known to be a species very similar to $P$. amphibius and the taxonomic status of $P$. amphibius is questionable (Pethiyagoda \& Kottelat 2005). $P$. melonostigma recorded by Raghunathan et al. (2008) is being considered as $P$. mahecola (Pethiyagoda \& Kottelat 2005).

Barring these, of the 66 species reported by earlier surveys, eight species were not recorded during the present study, while 17 others were added for the first time to the list of fishes known from Chennai. Thus, during the present study the presence of 75 species of fish has been validated. This is the highest number of primary freshwater fish species reported from Chennai and its environs. The eight 'missing' species are Nandus nandus, Clarias magur, Ompok bimaculatus, Sperata aor, Cirrhinus reba, Salmostoma acinaces, Puntius amphibius and Anguilla bengalensis. Poecilia reticulata, Xiphophorus helleri, $X$. maculatus and Brachydanio rerio reported from Chennai (Devi et al. 1999) have not been included in the checklist, as they were collected from a farm and not in the wild.

Four species of fish have been recorded after 100 years. Raj (1916) recorded Anguilla bicolor, Labeo calbasu, Wallago attu, Channa gachua in the year 1910-11 and these fish which were not reported in any other surveys were collected during the present study. Macrognathus aral though not collected in the recent study was captured from Chembarampakkam recently (E. Ramanujam pers. comm.). The non-native Osphronemus gourami is one other species not collected in the present study but has been added to the checklist as there is a recent report of its presence in the Adyar River (Knight 2010a).

Exotic fish recorded for the first time can be attributed to more recent introductions by the ornamental fish trade and aquaculture. Species like Pterygoplichthys disjunctivus, P. pardalis, Hemichromis bimaculatus and Amphilophus trimaculatum (Knight \& Devi 2009a) are sure to have been brought in by the aquarium trade. Clarias gariepinus, Pangasius pangasius, Oreochromis niloticus, O. aureus (Knight \& Devi 2009b) and the large carps have been brought in for aquaculture.

The recent record of northern Indian fish like Badis badis (Knight \& Devi 2009c), Puntius gelius (Knight $2010 \mathrm{~b})$ and $P$. orphoides are rather interesting. These may have been brought in by the Krishna water transported to Chennai recently or earlier by ways of water imports from the north. What is more interesting is that these fish neither feature in the list of fishes of Hyderabad (Chandrasekhar 2004) which includes those of the River Krishna nor in the checklist of fishes of the River Krishna (Jayaram 1995).

Eighty-three species of fishes belonging to 49 genera and 23 families are known to inhabit the fresh water habitats of Chennai (Table 1). The presence of almost $90 \%$ of the fishes known in the past 100 years was validated in the present study, highlighting that species do persist. Conclusions and reports of species extinction can well be premature and misleading.

\section{REFERENCES}

Bai, M.M. (1993). Ecological Studies on the River Cooum with special reference to pollution. Records of the Zoological Survey of India 93 (3-4): 393-416.

Chandrasekhar, S.V.A. (2004). Fish fauna of Hyderabad and its environs. Zoos' Print Journal 19(7): 1530-1533.

Daniels, R.J.R. (2002). Freshwater Fishes of Peninsular India. Universities Press, Hyderabad, India, 288pp.

Daniels, R.J.R. \& B. Rajagopal (2004). Fishes of Chembarampakkam Lake - a wetland in the outskirts of Chennai. Zoos' Print Journal 19: 1481-1483.

Devi, K.R., T.J. Indra, M.B. Raghunathan \& M.M. Bai (1999). On a collection of fish fauna from Chennai; Chengleput and Tiruvallur districts of Tamil Nadu. Records of the Zoological Survey of India 97(Part 4): 151-166.

Evangeline, G. (1967). Trend in the fisheries of the Adyar Estuary from April 1963 to March 1965. Madras Journal of Fisheries 4: 1-20.

Ganapati, S.V. (1964). Hydrobiological study of the river Cooum in Madras, South India with special reference to fisheries. Arch Hydrobiol 60(2): 200-224.

Jayaram, K.C. (1995). The Krishna River system bioresources study. Records of the Zoological Survey of India, Miscellaneous Publication, Occasional Paper No. 160, $167 p p$.

Jayaram, K.C. (1999). The Freshwater Fishes of the Indian Region. Narendra Publishing House, New Delhi, 551pp.

Knight, J.D.M. (2010a). Invasive ornamental fish: a potential threat to aquatic biodiversity in Peninsular India. Journal of Threatened Taxa 2(2): 700-704.

Knight, J.D.M. (2010b). On a record of Puntius gelius (Hamilton, 1822) (Teleostei: Cypriniformes: Cyprinidae) from Tamil Nadu. Journal of Threatened Taxa 2(3): 786-787.

Knight, J.D.M. \& K.R. Devi (2009a). On a record of Amphilophus trimaculatum (Günther) (Teleostei: Perciformes: Cichlidae) in the natural waters of Tamil Nadu, India. Journal of the Bombay Natural History Society 106(3): 347-348.

Knight, J.D.M. \& K.R. Devi (2009b). Record of Oreochromis aureus (Steindachner, 1864) (Teleostei: Perciformes: Cichlidae) in the natural waters of Tamil Nadu, India. Taprobanica 1(2): 126-129.

Knight, J.D.M. \& K.R. Devi (2009c). On a record of Badis badis (Hamilton) (Teleostei: Perciformes: Badidae) from Tamil 
Table 1. A consolidated list of the fishes of Chennai

\begin{tabular}{|c|}
\hline Family / Scientific name \\
\hline Notopteridae \\
\hline 1. Notopterus notopterus (Pallas 1769) \\
\hline Anguillidae \\
\hline 2. Anguilla bengalensis (Gray 1831$)^{*}$ \\
\hline 3. Anguilla bicolor McClelland 1844 \\
\hline Cyprinidae \\
\hline 4. Amblypharyngodon microlepis (Bleeker 1854) \\
\hline 5. Amblypharyngodon mola (Hamilton 1822) \\
\hline 6. Chela cachius (Hamilton 1822) \\
\hline 7. Cirrhinus cirrhosus (Bloch, 1795) \\
\hline 8. Cirrhinus reba (Hamilton 1822)* \\
\hline 9. Ctenopharyngodon idellus (Cuvier \& Valenciennes 1844) \\
\hline 10. Cyprinus carpio Linnaeus 1758 \\
\hline 11. Esomus barbatus (Jerdon 1849) \\
\hline 12. Esomus danricus (Hamilton 1822) \\
\hline 13. Esomus thermoicos (Hamilton 1822) \\
\hline 14. Gibelion catla (Hamilton 1822) \\
\hline 15. Horadandia atukorali Deraniyagala 1943 \\
\hline 16. Hypophthalmichthys nobilis (Richardson 1845) \\
\hline 17. Labeo calbasu (Hamilton 1822) \\
\hline 18. Labeo rohita (Hamilton 1822) \\
\hline 19. Laubuca laubuca (Hamilton 1822) \\
\hline 20. Osteobrama cotio peninsularis (Silas 1952) \\
\hline 21. Parluciosoma daniconius (Hamilton 1822) \\
\hline 22. Puntius amphibius (Valenciennes 1842$)^{\star}$ \\
\hline 23. Puntius chola (Hamilton 1822) \\
\hline 24. Puntius conchonius (Hamilton 1822) \\
\hline 25. Puntius dorsalis (Jerdon 1849) \\
\hline 26. Puntius filamentosus (Valenciennes 1844) \\
\hline 27. Puntius gelius (Hamilton 1822) \\
\hline 28. Puntius mahecola (Valenciennes 1844) \\
\hline 29. Puntius orphoides (Valenciennes 1842) \\
\hline 30. Puntius sarana subnasutus (Valenciennes 1842) \\
\hline 31. Puntius sharmai Menon \& Rema Devi 1993 \\
\hline 32. Puntius sophore (Hamilton 1822) \\
\hline 33. Puntius ticto (Hamilton 1822) \\
\hline 34. Puntius vittatus (Day 1865) \\
\hline 35. Rasbora caverii (Jerdon 1849) \\
\hline 36. Salmophasia acinaces (Valenciennes 1844$)^{*}$ \\
\hline 37. Salmophasia bacaila (Hamilton 1822) \\
\hline 38. Salmophasia clupeoides (Bloch 1795) \\
\hline Cobitidae \\
\hline 39. Lepidocephalichthys guntea (Hamilton 1822) \\
\hline 40. Lepidocephalichthys thermalis (Valenciennes 1846) \\
\hline
\end{tabular}

\begin{tabular}{|c|}
\hline Family / Scientific name \\
\hline Bagridae \\
\hline 41. Sperata aor (Hamilton 1822)* \\
\hline 42. Mystus bleekeri (Day 1877) \\
\hline 43. Mystus cavasius (Hamilton 1822) \\
\hline 44. Mystus gulio (Hamilton 1822) \\
\hline 45. Mystus keletius (Valenciennes 1840) \\
\hline 46. Mystus vittatus (Bloch 1794) \\
\hline Siluridae \\
\hline 47. Neotropius atherinoides (Bloch 1794) \\
\hline 48. Ompok bimaculatus (Bloch 1794)* \\
\hline 49. Wallago attu (Bloch \& Schneider 1801) \\
\hline Pangasiidae \\
\hline 50. Pangasius pangasius (Hamilton 1822) \\
\hline Clariidae \\
\hline 51. Clarias magur (Hamilton 1822)* \\
\hline 52. Clarias gariepinus (Burchell 1822) \\
\hline Heteropneustidae \\
\hline 53. Heteropneustes fossilis (Bloch 1794) \\
\hline Loricariidae \\
\hline 54. Pterygoplichthys disjunctivus (Weber 1991) \\
\hline 55. Pterygoplichthys pardalis (Castelnau 1855) \\
\hline Adrianichthyidae \\
\hline 56. Oryzias dancena (Hamilton 1822) \\
\hline Belonidae \\
\hline 57. Xenentodon cancila (Hamilton 1822) \\
\hline Aplocheilidae \\
\hline 58. Aplocheilus parvus (Sundara Raj 1916) \\
\hline Poecilidae \\
\hline 59. Gambusia affinis (Baird \& Girard 1853) \\
\hline Mastacembelidae \\
\hline 60. Macrognathus aral (Bloch \& Schneider 1801) \\
\hline 61. Macrognathus pancalus Hamilton 1822 \\
\hline 62. Mastacembelus armatus (Lacepede 1800) \\
\hline Chandidae \\
\hline 63. Chanda nama Hamilton 1822 \\
\hline 64. Parambassis lala (Hamilton 1822) \\
\hline 65. Parambassis ranga (Hamilton 1822) \\
\hline Nandidae \\
\hline 66. Badis badis (Hamilton 1822) \\
\hline 67. Nandus nandus (Hamilton 1822)* \\
\hline Cichlidae \\
\hline 68. Amphilophus trimaculatum (Gunther 1867) \\
\hline 69. Etroplus maculatus (Bloch 1795) \\
\hline 70. Etroplus suratensis (Bloch 1790) \\
\hline
\end{tabular}




\begin{tabular}{|l|}
\hline Family / Scientific name \\
\hline 71. Hemichromis bimaculatus Gill 1862 \\
\hline 72. Oreochromis aureus (Steindachner 1864) \\
\hline 73. Oreochromis mossambicus (Peters 1852) \\
\hline 74. Oreochromis niloticus (Linnaeus 1758) \\
\hline Gobiidae \\
\hline 75. Glossogobius giuris (Hamilton 1822) \\
\hline Anabantidae \\
\hline 76. Anabas testudineus (Bloch 1792) \\
\hline Belontiidae \\
\hline 77. Colissa lalia (Hamilton 1822) \\
\hline 78. Pseudosphromenus cupanus (Cuvier 1831) \\
\hline 79. Trichogaster trichopterus (Pallas 1770) \\
\hline Osphronemidae \\
\hline 80. Osphronemus gourami (Lacepède 1801) \\
\hline Channidae \\
\hline 81. Channa gachua (Hamilton 1822) \\
\hline 82. Channa punctatus (Bloch 1793) \\
\hline 83. Channa striatus (Bloch 1793) \\
\hline Species included only on basis of previous 1 (Pureys 180 \\
\hline
\end{tabular}

* - Species included only on basis of previous surveys
Nadu. Journal of the Bombay Natural History Society 106(2): 329-330.

Menon, A.G.K. (1999). Check list - fresh water fishes of India. Records of the Zoological Survey of India, Miscellaneous Publication, Occasional Paper No. 175, 366pp.

Panikker, N.K. \& R.G. Aiyar (1937). The brackish-water fauna of Madras. Proceedings of the Indian Academy of Science 6: 284-337.

Parenti, L.R. (2008). A phylogenetic analysis and taxonomic revision of ricefishes, Oryzias and relatives (Beloniformes, Adrianichthyidae). Zoological Journal of the Linnean Society 154: 494-610.

Pethiyagoda, R. \& M. Kottelat (2005). The identity of the south Indian barb Puntius mahecola (Teleostei: Cyprinidae). Raffles Bulletin of Zoology Supplement 12: 145-152.

Raghunathan, M.B. (1978). Studies on seasonal tanks in Tamil Nadu. 1. Chembarampakkam tank. The Indian Journal of Zootomy 19(2): 81-85.

Raghunathan, M.B., K.R. Devi \& T.J. Indra (2005). Studies on the icthyofauna of sacred groves in Kanchipuram District, Tamil Nadu. Records of the Zoological Survey of India 104(Part 1-2): 59-69.

Raghunathan, M.B., K.R. Devi \& T. J. Indra (2008). Fish faunal diversity in a paddy field from TamilNadu. Records of the Zoological Survey of India 108(Part 2): 51-65.

Raj, S.B. (1916). Notes on the freshwater fish of Madras. Records of the Indian Museum XII (Part VI): 249-294.

Talwar, P.K. \& A.G. Jhingran (1991). Inland Fishes of India and Adjacent Countries Vol 1. A.A. Balkema, Rotterdam, 541pp. 